Annals of Warsaw University of Life Sciences - SGGW

Land Reclamation No 46 (2), 2014: 125-138

(Ann. Warsaw Univ. of Life Sci. - SGGW, Land Reclam. 46 (2), 2014)

\title{
Using the River Habitat Survey method in forecasting effects of river restoration
}

\author{
MARTA KIRAGA, ZBIGNIEW POPEK \\ Department of Hydraulic Engineering \\ Warsaw University of Life Sciences - SGGW
}

\begin{abstract}
Using the River Habitat Survey method in forecasting effects of river restoration. Research presents usability of the River Habitat Survey (RHS) evaluation method in forecasting effects of the Zielawa River restoration, performed in selected section between $18+960 \mathrm{~km}$ and $19+460 \mathrm{~km}$. The EU so-called Water Framework Directive signalizes necessity of achieving a good ecological status of European rivers in the immediate future. Accordingly, river restoration is the main tool for already technically regulated rivers' quality upgrading. Present research contains a collation of four proposed restoration works variants and the ecological evaluation of chosen river reach before and after initiating restoration works in accordance to various variants, using the RHS method. The conclusion is fact, that in dependence of established variant it is possible to receive improvement of ecological class from present Class V to Class IV (variants 1 and 2) or Class III (variants 3 and 4).
\end{abstract}

Key words: river restoration, evaluation of restoration effect, the Zielawa River

\section{INTRODUCTION}

\section{Study field background}

The main aim of river restoration is ecological status improvement of already regulated rivers in a technical manner, that commonly activates significant changes of major channels' morphology (Żelazo and Popek 2002). Accordingly, the important element of formulation the river restoration concept is evaluation research of proposed river bed shape schemes' impact on ecological values improvement. It is proposed using the River Habitat Survey (RHS) method for achieve mentioned aim.

The RHS method is used for rivers' status evaluation on the grounds of hydromorphological conditions, as a resultant of accurately defined parameters, describing river and valley (Szoszkiewicz et al. 2008). The method's features are precision, reproducibility of scores, facility of carrying out a statistical analysis of obtained results. Elements of environment are evaluated objectively, the method performance is quite cheap and easy to carry out at once. The RHS method is applied in river classification with chosen reference conditions pursuant to EU so-called Water Framework Directive - WFD (2000). Results of already carried out experiments (1997-2008) validate that the RHS method can be successfully used in Poland (Jusik and Szoszkiewicz 2010). 
The evaluation of hydromorphological status is one of adjuvant criterions in recognizing the ecological quality of rivers, as well as physicochemical quality of the water. According to WFD, the essential significance in rivers' classification belong to biological elements, which have the biggest impact for river ecosystems' ecological quality (WFD). It is recommended to evaluate biological conditions on the basis of macrophytes, fishes, benthic invertebrates and phytoplankton research. In the RHS method there is considered incidence of macrophytes and, partially, animals from among previously mentioned scope of biological elements. Nevertheless, research data (Armitage and Pardo 1995, Kemp et al. 2000, Popek and Wasilewicz 2004, Sawa and Popek 2011) indicate that there is an exact connection between river's morphological and environment's biotic qualities, hence, the RHS method is commonly used for rivers' ecological valorization in Switzerland, Germany, Czech Republic, Denmark, Latvia and also, in a modified form, in Italy, Greece and Portugal, whereas in Poland it has been used mainly in scientific research, since mid-1990s. Present thesis represents an example of using the RHS method in forecasting the Zielawa River restoration effects (Baran 2013).

\section{The River Habitat Survey method}

The River Habitat Survey (RHS) method has been established in United Kingdom, where has been exploited since 1990s. Nowadays RHS is used in hydromorphological evaluation of homogenous river section (not surface water bodies) and is compatible to European standard PN-EN 14614:2008P (Ilnicki et al. 2009).
The RHS hydromorphological parameters, recognized both in spot-checks and also along the 500-meter reach of river, give an image of river's values as a natural ecosystem. River and offshore zone quality is shown as two numeric indexes, which are resultant of single basic parameters - HQA (Habitat Quality Assessment) and HMS (Habitat Modification Score). First index informs about a level of naturalness of examined river section (both in spot-checks and in 50-meter sections between them), whereas the second allows to achieve a numeric description of amount and genre of modifications, which are results of recently carried out river regulation, commonly made in accordance to technical rules.

Habitat Quality Assessment allows to execute naturally existing morphological elements of river and its valley diversity description. The outcome is also influenced by such parameters, as discharge type, fraction of bottom material, natural morphological elements of banks and river bed, structure and diversity of water and riparian vegetation, the number of bars, evincing natural erosion and accumulation processes. Moreover, there are evaluated such parameters, as a manner of land occupation in distance of $50 \mathrm{~m}$ from banks summit, forest cover and morphological elements connected with forests and environmentally valuable elements of river ecosystem, for example the presence of waterfalls, effluxes of groundwater. High score of HQA indicates significant number and high diversity of morphological natural elements in a river channel and in surrounding area (Jusik and Szoszkiewicz 2010). 
Habitat Modification Score describes a total degree of anthropogenic hydromorphological changes. It is as well resultant of all forms of initial status transformation, noticed in RHS field research. There are included such parameters, as quantity and size of particular types of water structures (dams, crossings, culverts, groynes, bridges), anthropological bank profiles transformations (reinforcing, resectioning, mitral channeling, embanking, bank devastation by cattle, riparian plants mowing), bottom modifications (reinforcing, resectioning, dredging, artificial bottom material, carving water plants). Low HMS values indicates the lack of modification or also insignificant hydromorphological transformations of rivers, whereas high HMS indicates intensified changes (Jusik and Szoszkiewicz 2010).

HQA and HMS numeric indexes are inversely proportional to each other. On the grounds of rivers the Narew, the Supraśl and the Słoja researches results (Giełczewski 2011) it has been appointed Pearson product-moment correlation (r) coefficient between variables, represented by both mentioned indexes. Received result $r=-0.36$ indicates soft connection, however minus value signalizes the downside ratio between numeric values of HQA and HMS indexes. This point is a consequence of fact that two various river sections with similar ecological qualities can be characterized by different anthropogenic influence. Anthropogenic transformations, if given to correct direction, not necessarily lead to significant rivers' hydromorphological quality deterioration. The higher value of HMS index - thence stronger is habitat transformation, thus, the more advanced are processes leading to differ the habitat from the natural status. Less anthropologic incursion in morphology and habitat functioning, i.e. different technical transformations, indicates more natural qualities of habitat and, conversely, highly transformed habitat could not be admitted as established just by the nature forces.

Field studies as per the RHS method are conducted in two steps in 500-meter river section. First step includes basic morphological attributes analysis, both in river bed and also in riparian zone, in 10 spot-checks, situated evenly with distances of $50 \mathrm{~m}$. In cross sections there are researched mainly physical attributes, for example a type of the water discharge, type and volume of accumulated bed load, intensity of embankment erosion, channel and banks substrate, type of current transformations, presence of technical forms of bed and banks reinforcing (Fig. 1). It is also considered presence and diversification of water and riparian plants and littoral zone land use regime as well (Szoszkiewicz et al. 2008).

Second step of RHS field studies comprises the synthetic description of the whole 500-meter river section. Research centres upon identification all present morphological forms and recognising channel transformations, which were not noticed in first step of field research, and moreover enables implementation of river valley depiction and delineation dimensions of river bed cross section - banks height, channel width and depth. Plus, it is defined amount and type of present water structures, swift currents, side and point bars and other elements (Szoszkiewicz et al. 2008). 


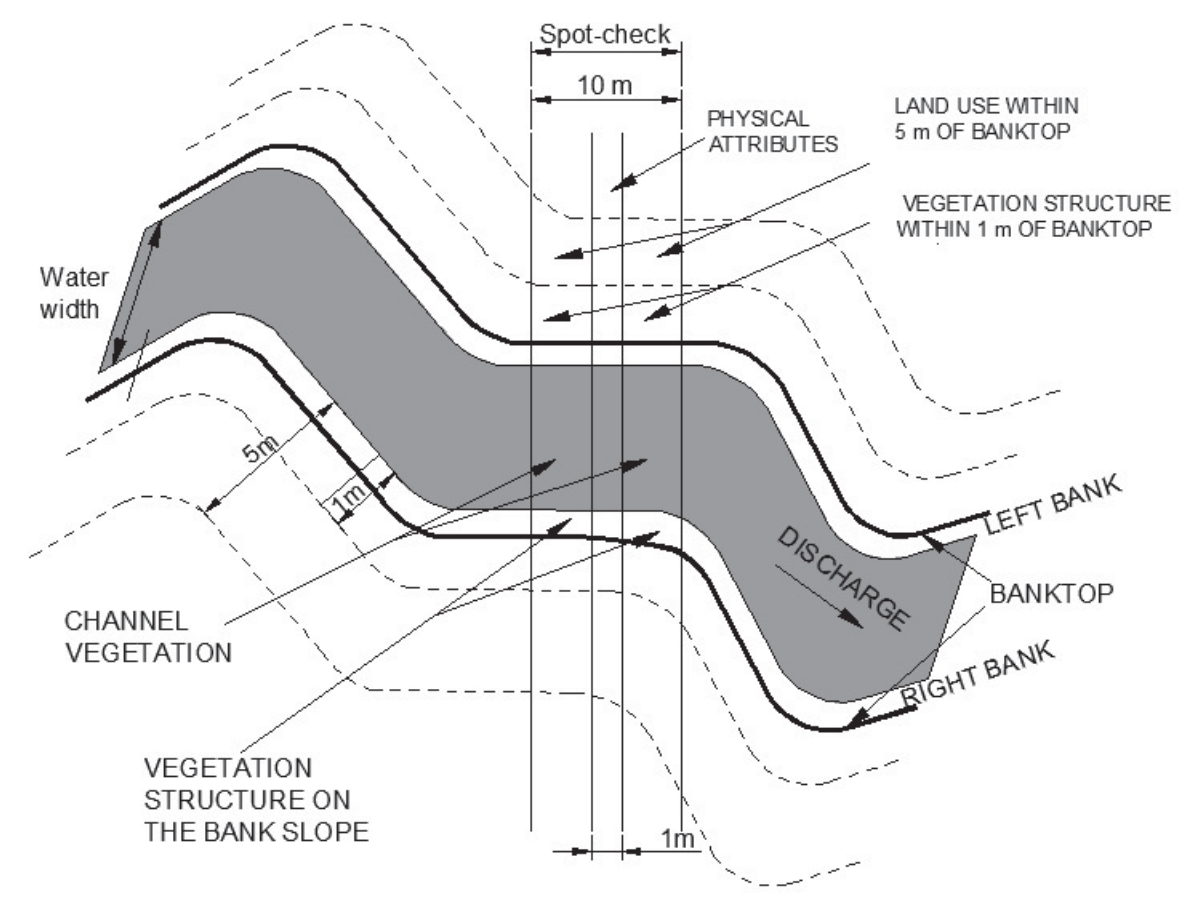

FIGURE 1. Dimensions of researched sections in spot-checks (Szoszkiewicz et al. 2008)

\section{The summary of characteristics and the range of restoration operations}

The aim of river restoration is reinstating to already regulated river bed that kind of ecological status, which could be recognized as natural. That kind of status definition could turn out as quite problematic because of continuity and persistence of natural transformations, thence it is assumed that the "ecological" will be named the status in which natural channel-forming processes dominate. Thus the identification of factors, that bring morphological transformation of a river is very important. The most common causes are radical changes as a consequence of river restoration, including channel realignment, steep stream slope, cross sections' shapes and dimensions standardizing, elimination of bottom and banks shapes irregularity, ecotones degradation, connections detachment between oxbow lakes and main river channel, flood range and time limitation and also draining polluted water, causing physic-chemical quality of water degradation (Żelazo 2006).

River restoration is not only active reconstruction of existent river bed, but also autonomous river and valley transformation, developed mainly in natural processes and anthropologic activity as a support (i.e. appropriate maintenance of river bed and water vegetation management). Thus river restoration is a long-lasting process, which effects are difficult to predicted thoroughly. Restoration procedures could 
be accomplished in a river bed area, a coastal environment, a valley zone, tributaries and moreover in a drainage basin (Żelazo and Popek 2002, Żelazo 2006). There are distinguished two parts in river restoration process. First of them is united with changes of abiotic river bed features, i.e. channel pattern, differentiation of vertical river bed shapes and cross sections. Modification of a horizontal shape of channel comes down to creation a curvilinear meandering channel conception, which is characterised by variable width and different river structures (bays, islands, shallows and branches). If there are oxbows in a river run, it is recommended to connect them with main channel. Modification of horizontal profile is as well connected with achieving depth diversification in cross sections (pools and riffles sequences). Common practice is also moderate the negative impact of presence water structures and communication buildings - in some cases it could be necessary to extract them from channel. It is possible also to rebuild cross sections of the river bed, what leads to shapes and dimensions changes in purpose to enhance a wider variety and better adaptation to horizontal plan of the river channel. Present technical embankments should be replace by river bank revetment made of natural or biotechnical materials. The essential impact for a bank stabilisation has an introduction of plants with a solid root system above all. In the second part of restoration, as a result of a natural flora succession, there is following biocoenosis wider spreading.

Restoration works require circumscription of main processes and elements that changed a river and led to unwanted condition (Żelazo and Popek 2002). Therefore river restoration should be preceded by recognition, based on hydrological, hydraulic and environmental problems (Żelazo 2006).

Before taking an investment it should be recognised hydromorphological quality of the river or a section, destined to modify. Attribution numeric values to each hydromorphological elements, assayed in RHS research, allows identification of those elements, which should be deliberated in describing the range and feature characteristics of bed and offshore zone restoration works schedule (Szoszkiewicz et al. 2008).

\section{MATERIAL AND METHODS}

\section{Methodology}

The basis for RHS hydromorphological status evaluation of a river are field studies, based on monitoring, according to assumed advices, the chosen river section and adjacent area. In order to appropriate field test developing, it is recommended for a research team to have a field blank sheet on a stiff board, field research key, range pole, camera and GPS. If an area of planned research is a private property, it should be asked the owner about entry permission (Szoszkiewicz et al. 2008).

A 4-page field sheet is divided into parts and sections. First part (sections A-D) includes informations about single spot-check and personal data of each member of the survey team. A-section, besides those details, contains also survey position characteristics, timespan, devices and conditions of measurements performing. B-section describes main shape of valley profile. C-section comprises 
number of riffles and pools. D-section gives an information about amount and type of water structures (Szoszkiewicz et al. 2008).

Next survey part, represented by sections $\mathrm{E}-\mathrm{G}$, allows spot-check data saving, particularly about dominating banks, river bed and valley attributes in 10 spot-checks, deployed in distance of about $50 \mathrm{~m}$. It is evaluated river bed load substrate, banks material, predominant flowtype, attributes connected with channel modification (sections $\mathrm{E}$ and $\mathrm{F}$ ) and natural environmental elements $(\mathrm{G})$, including water plants without species identification (Szoszkiewicz et al. 2008).

Third section is represented by sections $\mathrm{H}-\mathrm{L}$ and contains a synthetic score of chosen river section, thereupon there are accounted elements skipped during completing a spot-check description. Sections $\mathrm{H}$ and I evaluate conterminous land use and also banks profiles features, mainly natural elements of environment (for example underwater tree roots), which even inconsiderable participation $(<1 \%$ in chosen river section) influences significantly for a synthetic score of section. J-section describes forest and shrubs cover and accompanying to them environmental elements, i.e. presence of thick timber branches in a channel. The range of specific environmental attributes occurrence is registered in $\mathrm{K}$-section. L-section contains cross section dimensions, the measurement should be taken in appropriate standard position, not necessarily in spot-check ambit. The most proper tool for taking a measurement is range pole (Szoszkiewicz et al. 2008).

Evaluation considers also environmentally valuable river habitat elements and presence of invasive types of plants. Identification of those parameters comprises a separate part (sections $\mathrm{M}-\mathrm{O}$ ). In M-section it is noticed the presence of uniquely environmentally valuable attributes. N-section characterises channel permeability - if channel is heavily vegetated, especially in the period of maximal expansion, the permeability of channel decreases. The presence of expansive neophytes is noticed in O-section (Szoszkiewicz et al. 2008).

All additional informations are placed in sections $\mathrm{P}$ and $\mathrm{R}$. The first one is a general characteristic of a river section with environmental enhancing elements, including description of significant anthropologic impact and also the presence of definite animals species. In $\mathrm{R}$-section there is a filling the blank accuracy control (Szoszkiewicz et al. 2008).

The necessary condition of acquiring the precise scores is exact and careful blank completion by instructed research team with a sufficient knowledge in the environmental engineering, ecological and botanical scope. Survey is also evidenced by a set of adequate described photographs. Filled blanks are validated in the process of entering data into the computer database The STAR River Habitat Survey. Numeric HQA and HMS values are computed by a software, basing on input data.Verification a river reach restoration impact for its hydromorphological status, shown as numeric indexes, is based on ability to modify already input attributes in each sections and also in synthetic description.

Modification of river course, as a significant element of restoration works spectrum, basically comes down to depicting a land survey map in Auto- 
Cad software, on the grounds of available topographic maps. Afterwards, such items as river channel, oxbows, ambits of cadastral parcels, contours of present buildings, tree localisation and also passageways are being applied on sketched map. It is possible to apply planned restoration changes on previously prepared map, concerning watercourse modification, technical embankments or all changes of the present status (Fig. 2a, 2b).

It is recommended to consider time impact factor for process of natural transformation, initiated by technical works. As an example, it could be cited change connected with vegetation expansion, which is often introduced purposely as a kind of restoration work nowadays. Directly after entering pioneer plants it would have lower impact for a river regime and channel morphology, than a full-developed vegetation, naturally supplemented by additional species. Plant communities will evolve into animal habitats over time. Therefore it is necessary to consider investment impact for ecological status not only directly after restoration works, but also 15-20 years after biological and hydromorphological processes initiation.

According to WFD guidelines, it is differentiated five hydromorphological river quality classes for whom referential HQA and HMS values are shown on Figure 3 (Walker et al. 2002).

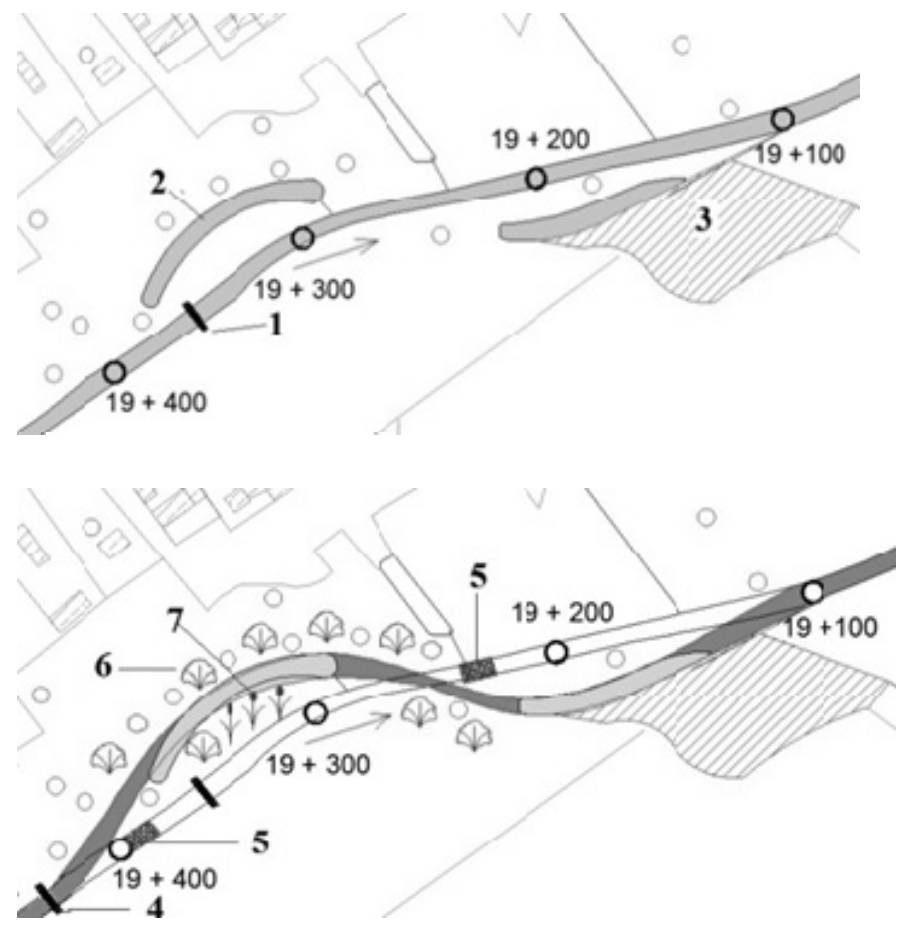

FIGURE 2. Excerpt of river reach map: a) present status, b) planned course modification; 1 - existing cross way for pedestrians, 2 - oxbow temporarily flooded, 3 -deciduous forest, 4 -designed cross way for pedestrians, 5 - low permeable stone sill, 6 - designed shrubs and scrubs, 7 - designed rushes 


\begin{tabular}{|c|c|c|c|c|c|c|}
\hline & \multicolumn{5}{|c|}{ Habitat Quality Assessment (HQA) value categories } \\
\hline & & Upper $20 \%$ & Upper $40 \%$ & $40 \%-60 \%$ & Lower $40 \%$ & Lower $20 \%$ \\
\hline \multirow{5}{*}{ 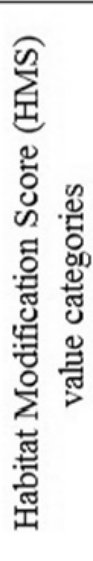 } & $\begin{array}{c}\text { natural } \\
(\text { HMS } 0 \text { - 2) }\end{array}$ & I & II & II & III & III \\
\hline & $\begin{array}{c}\text { low } \\
\text { modified } \\
(\text { HMS } 3-8)\end{array}$ & II & II & III & III & IV \\
\hline & $\begin{array}{c}\text { moderate } \\
\text { modified } \\
(\text { HMS } 9 \text { - 20) }\end{array}$ & III & III & III & IV & IV \\
\hline & $\begin{array}{c}\text { significantly } \\
\text { modified } \\
\text { (HMS 21- 44) }\end{array}$ & III & IV & IV & IV & $\mathrm{V}$ \\
\hline & $\begin{array}{c}\text { strongly } \\
\text { modified } \\
(\mathrm{HMS}>45)\end{array}$ & IV & IV & V & $\mathrm{V}$ & $\mathrm{V}$ \\
\hline
\end{tabular}

FIGURE 3. Hydromorphological status classification on the grounds of HQA and HMS values, computed in accordance to RHS method (Walker et al. 2002)

\section{River reach characteristic features}

The Zielawa River is about $68 \mathrm{~km}$ long and has about $1,146.38 \mathrm{~km}^{2}$ river basin area (Czarnecka 2005). The river is right the Krzna River confluent and it is situated in Lubelskie Voivodeship, in Bialski District (Fig. 4).
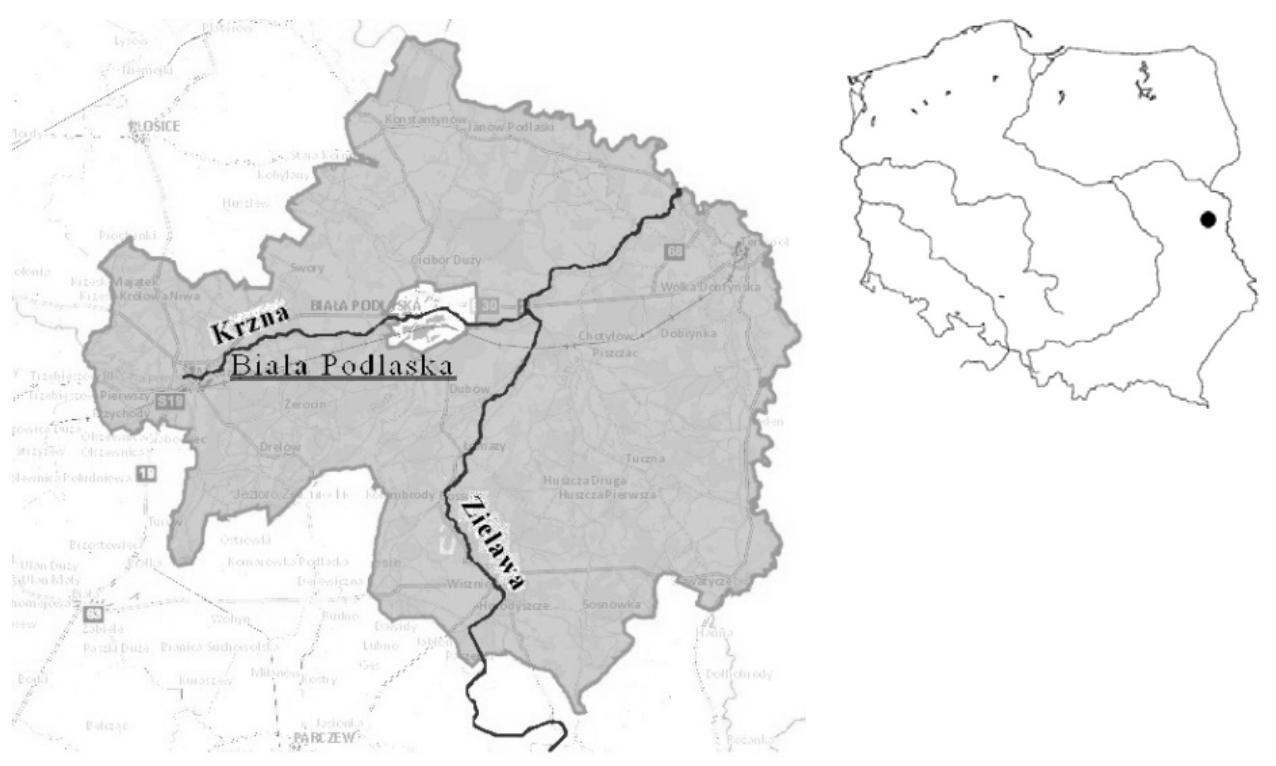

FIGURE 4. The Zielawa River situation in Bialski District 
The Zielawa River is situated in Polesie Lubelskie region (area $4,700 \mathrm{~km}^{2}$ ), that spreads on both sides of the Bug River and, in Polish borders, in upper part of the Prypeć River basin. Polesie Lubelskie is a plain area, partially covered by wetlands. The Zielawa River flows in north-east direction, empties to the Krzna River in $26+420 \mathrm{~km}$ (Czarnecka 2005).

Typical regional verdure are pine forests, alders with black alder substantially. Researched area is a land covered by grass and forest, which specific landscape accents are, besides agricultural areas, extensive used meadows, mixed forests and also woodlands.

The Zielawa River's feature are medium water resources - the average annual runoff rating from the basin equals $3.541 \cdot \mathrm{s}^{-1} \cdot \mathrm{km}^{-2}$. However, inequality of surface water runoff among lowland rivers is substantial- the WWQ and NNQ ratio equals 141 , yet maximal difference between water surface levels for those mentioned characteristic water discharges equals $2.55 \mathrm{~m}$. The comparison of characteristic water discharges in 1976-1990 in water gauge IMGW Perkowice profile on the Zielawa River is shown in Table 1.
River Habitat Survey evaluation experiments were ran on the river reach 500-meter length between $18+960 \mathrm{~km}$ and $19+460 \mathrm{~km}$ (Fig. 5). Such river part is situated in a typical rural Łomazy province, in a south direction from Biała Podlaska. There is no urban agglomeration in researched area. There were noticed cattle herds nearby the place which could be recognized as the centre of Łomazy and in the direct neighbourhood of typical small town urban buildings there was noticed the vast meadows and grassland areas.

Chosen river reach was already under strong stress in the past. In 1970s river bed was partially straightened, natural oxbows were dried and nowadays there are periodically flooded wetlands in a watercourse close neighbourhood. There are banks concrete slabs reinforcement and destroyed, concrete low weir in chosen section area $\left(4^{\text {th }}\right.$ cross section). All channel modification was introduced in accordance to technical rules, which did not consider necessity of saving river and valley ecological values. According to 1970 s rules, besides transformed horizontal shape of river bed, there were shape and dimensions of cross sections standardized and

TABLE 1. Characteristic discharges and water levels of the Zielawa River measured in water gauge Perkowice* (by Regional Water Management Board in Warsaw 2006)

\begin{tabular}{|l|l|c|c|}
\hline Mark & Description & Water level $(\mathrm{cm})$ & Discharge $\left(\mathrm{m}^{3} / \mathrm{s}\right)$ \\
\hline NNQ & The lowest multiannual discharge & 52 & 0.28 \\
\hline SNQ & Mean low discharge & - & 0.68 \\
\hline SSQ & Mean annual discharge & - & 3.38 \\
\hline SWQ & Mean high discharge & - & 17.0 \\
\hline WWQ & The highest multiannual discharge & 307 & 39.5 \\
\hline
\end{tabular}

*Location $-2.6 \mathrm{~km}, 955.2 \mathrm{~km}^{2}$ area, Level $0-133.51 \mathrm{~m}$ a.s.1. 


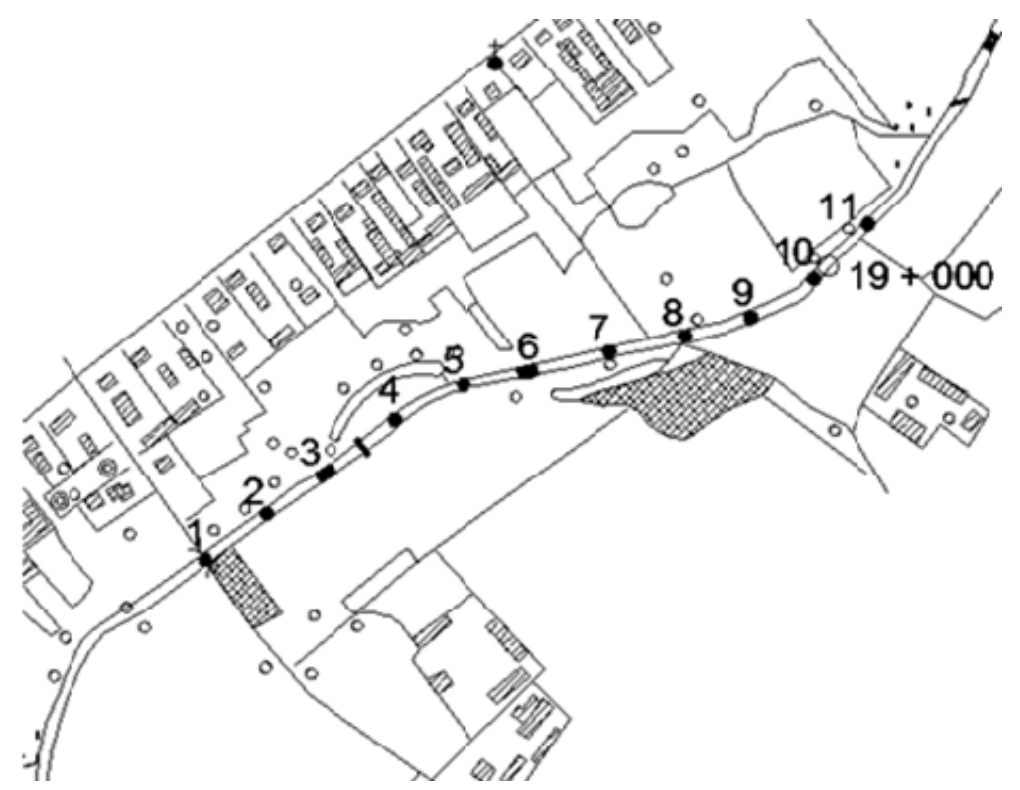

FIGURE 5. Wireframe of RHS evaluated river reach location

also cancelled the banks and bed irregularity and river branches.

At the present time the Zielawa River bed depth equals $1.7 \mathrm{~m}$, width $-7 \mathrm{~m}$ and banks inclination - about 1:2 (Baran 2013). While water level was near annual medium, the water depth in May 2013 equalled $0.95 \mathrm{~m}$.

\section{RESULTS AND DISCUSSION}

First step in hydromorphological quality evaluation of chosen river section was field survey, according to which paper blanks were filled. Then adequate values from blanks were introduced to The STAR River Habitat Survey Database software. It was considered couple of variants - Variant 0 , meaning the present state, and four others with various time steps and included works range. There are specified variants $0-4$ characteristics in Table 2, which are obviously different because of the river bed modification level and other additional both technical and biotechnical works, aimed at habitat ecological quality improvement.

HQA and HMS indexes values for Variant 0 were computed on the grounds of field survey, whereas for other variants there were considered planned works range as well as time. In Table 3 there is shown a tabulation of field survey results at first position and then evaluated changes of HQA and HMS computation outcomes as a result of introduction single restoration variants.

Basing on established referential values of HQA and HMS indexes (Fig. 3) the present river status (Variant 0 ) could be qualified as Class V (Table 3, Fig. 6), what indicates loss of natural river features.

Variant 1 assumes increasing of channel tortuosity through including oxbows and redirection water discharge to them by rock permeable steering structures 
TABLE 2. Variants characteristics and restoration works ranges

\begin{tabular}{|l|l|}
\hline Variant & \multicolumn{1}{|c|}{ Works range } \\
\hline Variant 0 & The present status \\
\hline Variant 1 & $\begin{array}{l}\text { Oxbows connecting, stone embankments, low permeable weirs introduction, } \\
\text { marshes development, slopes reinforcing by shrubs, scrubs, saplings and trees with } \\
\text { 5-year time step }\end{array}$ \\
\hline Variant 2 & $\begin{array}{l}\text { As above with concrete embankment and destroyed concrete weir elimination with } \\
\text { 5-year time step }\end{array}$ \\
\hline Variant 3 & As above with 20-year time step \\
\hline Variant 4 & $\begin{array}{l}\text { As above with bank fascine fortifications, stabilized by wooden pales with 20-year } \\
\text { time step }\end{array}$ \\
\hline
\end{tabular}

TABLE 3. HQA and HMS values for a present status of chosen reach of the Zielawa River and values after forecasting outputs of restoration works various ranges

\begin{tabular}{|l|c|c|c|}
\hline Variant & $\begin{array}{c}\text { Habitat Quality } \\
\text { Assessment (HQA) }\end{array}$ & $\begin{array}{c}\text { Habitat Modification } \\
\text { Score (HMS) }\end{array}$ & $\begin{array}{c}\text { The river reach } \\
\text { hydromorphological class }\end{array}$ \\
\hline Variant 0 & 36 & 51 & V \\
\hline Variant 1 & 34 & 15 & IV \\
\hline Variant 2 & 34 & 9 & IV \\
\hline Variant 3 & 46 & 9 & III \\
\hline Variant 4 & 48 & 13 & III \\
\hline
\end{tabular}

\begin{tabular}{|c|c|c|c|c|c|c|}
\hline & \multicolumn{5}{|c|}{ Habitat Quality Assessment (HQA) value categories } \\
\hline & & Upper $20 \%$ & Upper $40 \%$ & $40 \%-60 \%$ & Lower $40 \%$ & Lower $20 \%$ \\
\hline \multirow{5}{*}{ 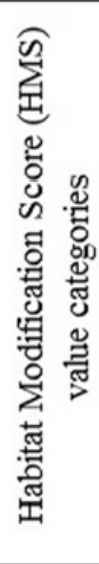 } & $\begin{array}{c}\text { natural } \\
\text { (HMS } 0-2)\end{array}$ & I & II & II & III & III \\
\hline & $\begin{array}{c}\text { low } \\
\text { modified } \\
(\text { HMS } 3-8)\end{array}$ & II & II & III & III & IV \\
\hline & $\begin{array}{c}\text { moderate } \\
\text { modified } \\
(\mathrm{HMS} 9-20)\end{array}$ & III & III & $4 \mathrm{n}$ & IV & IV \\
\hline & $\begin{array}{c}\text { significantly } \\
\text { modified } \\
\text { (HMS 21- 44) }\end{array}$ & III & IV & IV & IV & $\mathrm{V}$ \\
\hline & $\begin{array}{c}\text { strongly } \\
\text { modified } \\
(\mathrm{HMS}>45)\end{array}$ & IV & IV & $\mathrm{V}$ & $\mathrm{V}$ & V \\
\hline
\end{tabular}

FIGURE 6. Hydromorphological status evaluation on the grounds of HQA and HMS values: " 0 " - the present status V of researched river reach (variant 0), "1" and "2" - status IV after river restoration in variants 1 and 2, "3" and "4" - status III after 20-year time step (variants 3 and 4) 
and low weirs, that allow rising sandy bars in their neighbourhood in the future. Sandy bars - natural forms of bed load accumulation - should be self-covered by macrophytes in time, what contributes to increasing the number of places to hide and habitats for animals, connected with water ecosystem. It is recommended also marshes introducing at constant or temporarily flooded areas. It is planned shrubs and trees planting as natural embankments. Analysing Variant 1, with 5-year time step according to assumption, HQA and HMS values decreased (Table 3). However, adjustment was not acquired - the state could be classified as mediocre, Class IV (Fig. 6).

Variant 2 diverge from Variant 1 on obviating the concrete weir and embankment. As an effect the HMS value decreases - habitat modification score would be lower (Table 3), but that procedure would not lead yet to significant change of HQA value - river reach is still in Class IV (Fig. 6).

As a result variants 1 and 2 realisation, it is possible to increase hydromorphological quality barely with one class difference. Consequently it could be presumed river ecological quality advancement also, which ought to escalate regularly in time. In Variant 3 it is assumed the same works range as in Variant 2, but at once it is considered longer, 20-year time step, and, associated with it, further natural changes of channel morphology and natural plants introduction. Human activity would has a supporting character, restrained only to plant conservation and maintenance. It is assumed also further river beds forms composition, i.e. bank and bed sandy and gravel bars. Sandy bar could be formed in favourable conditions, for example, as a result water macrophytes overgrowing. According to forecasted effect in Variant 3 , the river reach would receive Class III of hydromorphological status, i.e. two classes higher than the present (Table 3, Fig. 6).

Horizontal shape modification leads to tortuosity channel growth, what could be the cause of concave banks erosion and necessity to embankments introduction. Variant 4 assumes using fascine stabilised with willow wooden pales. In 20 -year time step it is predicted riparian wicker thicket spreading, what may cause decreasing of habitat modification degree and also insignificant increasing of HQA value (Table 3). Still alteration of mentioned indexes does not induce hydromorphological status class change - it is invariably in Class III (Fig. 6).

\section{CONCLUSIONS}

On the grounds of field studies, performed on regulated reach of the Zielawa River, and forecasted restoration works effect it can be drawn following conclusions.

1. The River Habitat Survey method could be used not only for the present river reach hydromorphological status evaluation, but also for forecasting morphological and habitat changes impact, initiated by river restoration works.

2. River Habitat Survey's outcomes are emerged as numerous values, what gives feasibility of using data for comparative analysis of various design solutions and also ecological, fulfilled by nature's forces processes' impact in different time steps starting from realization restoration works. 
3. Using RHS method in forecasting river restoration impact basically comes to data modification in The STAR River Habitat Survey Database in each spot-checks of the new, designed channel, what leads to HQA and HMS alteration. Simultaneously, it is a possibility to take an analysis of factors, significantly impacting the final score.

4. Possible, but seldom, is more than one class hydromorphological status improvement - it requires both high amount of labour and money and moreover, correctly scheduled restoration process, which is the most important tool for technically modified river channels' ecological status improvement.

5. As computing simulation proofed, the Zielawa River's restoration begets, according to variants 1 and 2 , improvement of hydromorphological status from Class V to Class IV. Alteration of hydromorphological value of chosen river reach will also develop ecological status improvement as well. Restoration works would activate microhabitats creation, what would be the simply cause for enhancing channel and riparian area habitat conditions. Over time, as a result of realization Variant 3 or Variant 4 , the further progression of the Zielawa River reach hydromorphological status transpires - it is forecasted it could accomplish Class III of hydromorphological status.

\section{REFERENCES}

ARMITAGE P.D., PARDO I. 1995: Impact assessment of regulation at the reach level using macro invertebrate information from mesohabitats. Regulated River: Research and Management 10: 147-158.
BARAN M. 2012: Ocena stanu hydromorfologicznego małych rzek nizinnych według metody Ilnickiego. [The evaluation of hydromorphological status of small lowland rivers by Ilnicki's method]. Praca inżynierska, WBiIŚ SGGW, Warszawa [Engl. summ.].

CZARNECKA H. 2005: Atlas podziału hydrograficznego Polski. [Hydrographic Atlas of Poland]. IMGW, Warszawa [In Polish].

GIEŁCZEWSKI M. 2011: Ocena stanu hydromorfologicznego rzek na przykładzie metody RHS. [The evaluation of hydromorphological status of rivers on example RHS method]. Materiały dydaktyczne, WBiIŚ SGGW, Warszawa [In Polish].

ILNICKI P., GOŁDYN R., MURAT-BŁAŻEJEWSKA S., SOSZKA H., GÓRECKI K., GRZYBOWSKI M., KRZEMIŃSKA A., LEWANDOWSKI P., SKOCKI K., SOJKA M., MARCINKIEWICZ M. 2009: Opracowanie metodyk monitoringu i klasyfikacji hydromorfologicznych elementów jakości jednolitych części wód rzecznych i jeziornych, zgodnie z wymogami Ramowej Dyrektywy Wodnej. Etap II. [The elaboration of monitoring and classification methods of hydromorphological quality assesment of river and lake water bodies in accordance with Water Framework Directive. Stage II]. GEPOL, Poznań [in Polish].

JUSIK S., SZOSZKIEWICZ K. 2010: Możliwości wykorzystania system River Habitat Survey (RHS) na potrzeby wdrażania Ramowej Dyrektywy Wodnej w Polsce. [Possibilities of use of the River Habitat Survey to the needs of Water Framework Directive in Poland]. Acta Sci. Pol., Form. Circ. 9 (3): 23-34 [Engl. summ.].

KEMP J.L., HARPER D.M., CROSA G.A. 2000: The habitat-scale ecohydraulics of rivers. Ecological Engineering 6: 17-29.

PN-EN 14614:2008P: Jakość wody - Wytyczne do oceny hydromorfologicznych cech rzek. [Water quality - guidelines for hydromorphological quality assesment of riverbed]. Polski Komitet Normalizacyjny, Warszawa [in Polish].

POPEK Z., WASILEWICZ M. 2004: Porównanie charakterystyk morfologicznych odcinków koryta naturalnego i uregulowanego na przykładzie rzeki Wkry. [Comparison of morphological characteristics of natural and regulated river reaches based on example of the Wkra River]. Prz. Nauk. Inż. Kszt. Środ. 30: 128-137 [Engl. summ.]. 
SAWA K., POPEK Z. 2011: Analysis of the connection between hydromorphological conditions and biocenic diversity on the example of the Zwoleńka River. Ann. Warsaw Univ. of Life Sci. - SGGW, Land Reclam. 43 (2): 173-184.

SZOSZKIEWICZ K., ZGOŁA T., JUSIK S., HRYC-JUSIK B., DAWSON F., RAVEN P. 2008: Hydromorfologiczna ocean wód płynących. Podręcznik do badań terenowych według metody River Habitat Survey w warunkach Polski. [Hydromorphological quality assesment of rivers. Manual of using the River Habitat Survey system in Polish conditions]. Edition III. Centre for Ecology and Hydrology, Poznań - Warrington [in Polish].

WALKER J., DIAMOND M., NAURA M. 2002: The Development of Physical Habitat Objectives. Aquat. Conserv. Mar. Freshw. Ecosyst. 12: $381-390$.

Water Framework Directive 2000/60/WE (RDW) of 23 October 2000.

ŻELAZO J. 2006: Renaturyzacja rzek i dolin. [River and valley restoration]. Infrastruktura i Ekologia Terenów Wiejskich 4/1: 11-31 [Engl. summ.].

ŻELAZO J., POPEK Z. 2002: Podstawy renaturyzacji rzek. [Principle of river restoration]. Wyd. SGGW, Warszawa [In Polish].

Streszczenie: Prognozowanie efektów renaturyzacji rzeki z wykorzystaniem metody River Habitat Survey. W pracy przestawiono możliwość wykorzystania metody River Habitat Survey
(RHS) do oceny przewidywanych efektów renaturyzacji rzeki Zielawy na odcinku między $\mathrm{km} 18$ +960 a km $19+460$. Tak zwana Ramowa Dyrektywa Wodna nakłada konieczność osiąnnięcia w najbliższym czasie przez rzeki europejskie dobrego stanu ekologicznego. Renaturyzacja rzek jest głównym narzędziem poprawy jakości rzek, uregulowanych według wymagań technicznych. W artykule przedstawiono propozycję renaturyzacji odcinka rzeki Zielawy według czterech wariantów robót oraz dokonano oceny, wykorzystując metodę RHS, wpływu tych prac na poprawę obecnego stanu hydromorfologicznego rzeki. Stwierdzono, że w zależności od przyjętego wariantu robót poprawa stanu odcinka rzeki jest możliwa z obecnej V klasy do IV klasy (warianty 1 i 2) lub III klasy (warianty 3 i 4).

Stowa kluczowe: renaturyzacja rzeki, ocena skutków renaturyzacji, rzeka Zielawa

\section{MS. received in May 2014}

\author{
Authors' address: \\ Marta Kiraga, Zbigniew Popek \\ Wydział Budownictwa i Inżynierii Środowiska \\ SGGW \\ Katedra Inżynierii Wodnej \\ ul. Nowoursynowska 159 \\ 02-776 Warszawa, Poland \\ e-mail: marta_kiraga@sggw.pl \\ zbigniew_popek@sggw.pl
}

